\title{
Kajian Efektivitas Lansoprazol dan Pantoprazol sebagai Profilaksis Stress Ulcers di Intensive Care Unit (ICU)
}

\author{
Mega Octavia' ${ }^{1}$ Zullies Ikawati², dan Tri Murti Andayani² \\ 1 Departemen Farmasi Klinik, Fakultas Kedokteran dan Ilmu Kesehatan, Universitas Muhammadiyah Yogyakarta \\ ${ }^{2}$ Departemen Farmakologi dan Farmasi Klinik, Fakultas Farmasi, Universitas Gadjah Mada, Yogyakarta
}

Korespondensi: Mega Octavia

Email:megaoctavia88@gmail.com

Submitted : 15-11-2018, Revised : 23-01-2019, Accepted : 04-04-2019

\begin{abstract}
ABSTRAK: Resiko kejadian perdarahan meningkat pada pasien dengan kondisi kritis di intensive care unit (ICU) sehingga kebutuhan penggunaan profilaksis cukup tepat untuk mengurangi kejadian perdarahan selama di ICU. Kajian penggunaan profilaksis yang efektif sangat diperlukan untuk mencegah komplikasi tersebut dengan harapan dapat meminimalkan kejadian perdarahan saluran cerna pada pasien di ICU. Penelitian ini bertujuan untuk mengetahui efektivitas dan biaya penggunaan lansoprazol dan pantoprazol sebagai profilaksis stress ulcers di ICU rumah sakit di Yogyakarta. Penelitian ini merupakan penelitian non eksperimental dengan rancangan penelitian kohort retrospektif. Subjek penelitian adalah seluruh pasien rawat inap di ICU dengan usia $\geq 18$ tahun sampai 65 tahun yang mendapatkan terapi obat lansoprazol dan pantoprazol sebagai profilaksis stress ulcers selama bulan Januari 2014 - Desember 2016 yang memenuhi kriteria inklusi dan eksklusi. Penelitian dilakukan dengan membandingkan efektivitas terapi obat lansoprazol dan pantoprazol dengan melihat kejadian perdarahan minor dan mayor. Data penelitian dianalisis menggunakan Chi-Square untuk melihat perbedaan efektivitas antara 2 kelompok terapi. Dari total 119 pasien yang memenuhi kriteria inklusi, terdapat 48 pasien $(77,4 \%)$ dari kelompok terapi lansoprazol yang tidak mengalami kejadian perdarahan, sedangkan pada kelompok pantoprazol pasien yang tidak mengalami kejadian perdarahan sebanyak 35 pasien $(61,4 \%)$. Secara statistik efektivitas lansoprazol dan pantoprazol sebagai profilaksis untuk mengatasi kejadian perdarahan tidak berbeda signifikan $(\mathrm{P}=0,057)$. Dari penelitian ini dapat disimpulkan bahwa tidak terdapat perbedaan efektivitas antara lansoprazol dan pantoprazol sebagai profilaksis stress ulcers pada pasien dengan resiko tinggi perdarahan saluran cerna di ICU.
\end{abstract}

Kata kunci: profilaksis stress ulcers; lansoprazol; pantoprazol; intensive care unit

\begin{abstract}
The incidence of bleeding is increased in high risk patients with critical condition in intensive care unit (ICU). Appropriate prophylaxis medicine is necessary to reduce the incidence of stress ulcer bleeding during hospitalization in ICU. The aim of this research is to compare the effectivity between iv lansoprazole and iv pantoprazole as prophylaxis for stress ulcer bleeding in ICU settings. In this retrospective observational study, review was conducted on medical records of all patients admitted to ICU in a District Hospital in Yogyakarta from January 2014 until December 2016. The incidence of clinically significant and overt GI bleeding was recorded from the two groups. Data were analyzed using Chi-Square test to determine the difference between the two groups. A total of 119 high risk patients were included in this study: 62 patients in the lansoprazole group and 47 patients in the pantoprazole group. Fourty eight patients (77.4\%) from lansoprazole group and 35 patients (61.4\%) from pantoprazole group revealed neither overt nor clinically significant GI bleeding. There was also no statistical difference in the incidence of GI bleeding between the two groups (CI 95\%, $p<0.05)$. There is no difference regarding effectivity of lansoprazole and pantoprazole as prophylaxis for stress ulcer bleeding in high risk patients in intensive care unit (ICU) patients.
\end{abstract}

Keywords: stress ulcer prophylaxis; lansoprazole; pantoprazole; intensive care unit 


\section{Pendahuluan}

Pasien dengan kondisi kritis yang dirawat di unit perawatan intensif (ICU) memiliki resiko tinggi berkembang menjadi stress ulcers. Stress ulcers telah terbukti meningkatkan morbiditas dan mortalitas, dengan perdarahan yang berhubungan dengan perpanjangan length of stay antara 4 dan 8 hari dan meningkatkan angka kematian hingga 4 kali lipat. Hasil penelitian melalui endoskopi menunjukkan sebagian besar (75-100\%) dari pasien ICU memiliki gangguan kerusakan mukosa lambung dalam beberapa jam setelah masuk [1,2] dan setelah dilakukan uji cairan asam lambung hasilnya positif terdapat bleeding pada $35-100 \%$ pasien ICU [3].

Satu-satunya evidence based dan pedoman terapi untuk profilaksis stress ulcers diterbitkan oleh American Society of Health-System Pharmacists Guideline [3] menyatakan bahwa profilaksis stress ulcers harus diresepkan hanya untuk pasien yang berisiko tinggi mengalami kejadian perdarahan saluran cerna terutama pada pasien di unit perawatan intensif (ICU) . Terapi profilaksis stress ulcers yang paling umum digunakan pada praktek klinis adalah inhibitor pompa proton (PPI) dan histamin-2 antagonis reseptor (H2RA) [3,4]. Beberapa penelitian menyebutkan bahwa penggunaan PPI sebagai profilaksis stress ulcers lebih efektif dan lebih hemat dibandingkan dengan H2RA [5,6].

Lansoprazol dan pantoprazol termasuk golongan PPI generasi baru yang belum banyak diteliti sebagai profilaksis stress ulcers dibandingkan PPI generasi lama seperti omeprazol. Meskipun berada dalam golongan yang sama, efektivitas dari kedua obat tersebut bisa saja berbeda, hal ini disebabkan oleh perbedaan sifat farmakokinetiknya. Lansoprazol memiliki clearance yang lebih besar dari pantoprazol, waktu untuk mencapai konsentrasi maksimum lebih cepat dan bioavailabilitas lansoprazol juga lebih tinggi dari pantoprazol $[7,8]$.

Pada pasien di ICU, penggunaan PPI untuk profilaksis stress ulcers sebesar $47,9 \%$, peptic ul- cers disease $11,5 \%$ dan perdarahan saluran cerna sebesar 20,8\% [9]. Dari persentase di atas dapat diketahui bahwa penggunaan PPI untuk indikasi profilaksis lebih banyak dibandingkan indikasi lain di ICU. Tingginya penggunaan PPI sebagai profilaksis ini juga mempengaruhi biaya yang diperlukan pasien untuk perawatan di ICU. Dilatarbelakangi pentingnya penggunaan profilaksis untuk mencegah kejadian bleeding pada pasien dengan resiko tinggi, maka perlu untuk mengkaji obat profilaksis yang efektif untuk mencegah komplikasi tersebut. Dari literatur telah disebutkan bahwa penggunaan lansoprazol lebih efektif dan hemat sebagai profilaksis di ICU dan obat injeksi pantoprazol generik merupakan obat paling banyak digunakan sebagai profilaksis pada praktek kliniknya. Pada penelitian ini ingin dilihat apakah terdapat perbedaan efektivitas terapi antara lansoprazol dan pantoprazol sebagai profilaksis stress ulcers di ICU.

\section{Metode}

Penelitian ini merupakan penelitian observasional dengan rancangan penelitian kohort retrospektif pada pasien rawat inap yang menggunakan lansoprazol dan pantoprazol sebagai terapi profilaksis untuk stress ulcers di ICU Rumah Sakit di Yogyakarta. Data diambil dari rekam medik pasien pada Januari 2014 - Desember 2016.

\subsection{Kriteria inklusi dan eksklusi}

Subjek penelitian adalah seluruh pasien rawat inap ICU yang mendapatkan terapi obat pantoprazol atau lansoprazol sebagai profilaksis stress ulcers pada tahun 2014-2016 yang memenuhi kriteria inklusi dan eksklusi. Kriteria inklusi dari penelitian ini meliputi (1) Pasien dewasa, usia $\geq 18$ tahun - 65 tahun yang memiliki minimal satu faktor resiko dari: (a) Penggunaan ventilasi mekanik > 48 jam, (b) Koagulopati (INR > 1,5; PTT $>2 \mathrm{x}$ kontrol; Platelet $<50 \mathrm{ribu}$ ) dan dua faktor resiko dari (a) Syok hipotensi, (b) Syok sepsis,(c) Gagal hepar/gagal ginjal/gagal jantung, (d) Spi- 
nal cord injury,(e) Transplantasi hati /ginjal, (f) Luka bakar > 35\% luas permukaan tubuh, (g) Trauma: Pasca bedah mayor, pasca persalinan, pasca kemoterapi, (h) Head Injury (GCS $\leq 10)$, (i) Riwayat ulserasi lambung/bleeding dalam 1 tahun sebelum masuk RS, (j) ICU Stay > 1 minggu, (k) Kortikosteroid terapi (> $250 \mathrm{mg}$ atau yang sejenis); (2) Selama masa rawat inap di ICU pasien mendapatkan terapi obat pantoprazol atau lansoprazol minimal selama 1 hari atau 24 jam $[10,11]$. Kriteria eksklusi dari penelitian ini meliputi: pasien mendapat kombinasi obat penekan asam lambung lain selain pantoprazol dan lansoprazol, pasien yang masuk dengan diagnosa hematemesis dan melena, serta pasien yang masuk dengan diagnosa gastritis atau ulkus.

\subsection{Pengumpulan data}

Data yang dikumpulkan pada penelitian ini meliputi: (1) diagnosa pasien saat masuk dan selama di ICU, (2) karakteristik pasien seperti jenis kelamin, usia, lama rawat, skala GCS, jenis faktor resiko dan jumlahnya, (3) penggunaan obat profilaksis stress ulcers, (4) penggunaan obat-obatan lain selain profilaksis selama di ICU, serta (5) ada/tidaknya kejadian perdarahan (baik perdarahan mayor maupun minor).

\subsection{Clinical outcome}

Terapi efektif jika tidak terjadi perdarahan pada saluran cerna baik perdarahan minor maupun mayor. Perdarahan minor meliputi hematemesis, melena, hematocezhia, residu NGT berwarna merah dan/atau coklat kehitaman, sedangkan perdarahan mayor merupakan kejadian perdarahan minor yang diikuti oleh salah satu dari tekanan darah sistolik turun atau tekanan darah diastolik turun secara spontan $20 \mathrm{mmHg}$ atau lebih dalam 24 jam kejadian perdarahan, mulai menggunakan vasopressor atau terjadi peningkatan dosis vasopressor sebesar $20 \%$, penurunan $\mathrm{Hb}$ minimal $2 \mathrm{~g} / \mathrm{dl}$, kebutuhan transfusi 2 unit PRC atau lebih [12].

\subsection{Analisis data}

Efektivitas terapi dianalisis menggunakan ChiSquare dengan bantuan software SPSS 22 .

\section{Hasil dan pembahasan}

Penelitian ini telah melewati uji layak etik oleh komisi etik penelitian Fakultas Kedokteran UGM dengan No: 00527/KKEP/FKG-UGM/EC/2016. Data dari rekam medik yang memenuhi kriteria inklusi dan eksklusi sebanyak 119 pasien yang terbagi dalam 2 kelompok terapi yaitu 57 pasien menggunakan pantoprazol secara intravena dan 62 pasien menggunakan obat lansoprazol intravena.

\subsection{Karakteristik pasien}

Karakteristik dasar 119 pasien yang meliputi jenis kelamin, lama rawat di ICU, skala Glasgow Coma Scale (GCS), jumlah faktor resiko, dan jenis faktor resiko bleeding selama pasien dirawat di ICU dapat dilihat pada tabel 1. Sebagian besar karakteristik antara kelompok lansoprazol dan pantoprazol tidak memiliki perbedaan proporsi yang signifikan antara dua kelompok terapi kecuali ICU stay, jumlah faktor resiko, dan jenis resiko sepsis memiliki jumlah proporsi yang cukup berbeda signifikan $(\mathrm{P}<0,05)$ antara dua kelompok penelitian.

\subsection{Gambaran penggunaan obat-obat yang bersifat ulserogenik}

Selama mendapat perawatan di ICU, pasien mendapat obat-obatan untuk mengatasi masalah medis yang dialami. Peneliti akan membatasi pembahasan mengenai gambaran pengobatan hanya pada obat profilaksis stress ulcers dan obat- obat yang bersifat ulserogenik. Dari awal penelitian telah dibahas bahwa obat profilaksis stress ulcers yang digunakan di sini yaitu lansoprazol dan pantoprazol. Pemilihan dua obat dari golongan proton pump inhibitor (PPI) ini disebabkan oleh kedua obat tersebut paling banyak digunakan di ICU untuk golongan PPI. 
Tabel 1. Karakteristik pasien dengan resiko bleeding di bangsal ICU

\begin{tabular}{|c|c|c|c|}
\hline \multirow[t]{2}{*}{ Parameter } & \multicolumn{2}{|c|}{ Jumlah pasien (n, \%) } & \multirow[t]{2}{*}{ Nilai $P$} \\
\hline & Lansoprasol & Pantoprazol & \\
\hline $\begin{array}{l}\text { Jenis kelamin: } \\
\text { Laki-laki } \\
\text { Perempuan }\end{array}$ & $\begin{array}{l}44(71) \\
18(29)\end{array}$ & $\begin{array}{l}34(59,6) \\
23(40,4)\end{array}$ & 0,194 \\
\hline $\begin{array}{l}\text { Usia (tahun): } \\
18-30 \\
31-40 \\
41-65\end{array}$ & $\begin{array}{l}1(1,6) \\
3(4,8) \\
58(93,5)\end{array}$ & $\begin{array}{l}2(3,2) \\
3(4,8) \\
52(91,2)\end{array}$ & 0,592 \\
\hline Usia (mean $\pm \mathrm{SD})$ & $57,26 \pm 9,24$ & $55,98 \pm 9,54$ & 0,220 \\
\hline $\begin{array}{l}\text { ICU stay (hari): } \\
\leq 7 \\
>7\end{array}$ & $\begin{array}{l}49(79) \\
13(21)\end{array}$ & $\begin{array}{l}32(56,1) \\
25(43,9)\end{array}$ & $0,007^{*}$ \\
\hline $\begin{array}{l}\text { Skala GCS: } \\
\leq 10 \\
>10\end{array}$ & $\begin{array}{l}4(6,5) \\
58(93,5)\end{array}$ & $\begin{array}{l}10(17,5) \\
47(82,5)\end{array}$ & 0,061 \\
\hline $\begin{array}{l}\text { Jumlah faktor resiko: } \\
1-2 \\
3-4 \\
>4\end{array}$ & $\begin{array}{l}39(62,9) \\
22(35,5) \\
1(1,6)\end{array}$ & $\begin{array}{l}24(42,1) \\
29(50,9) \\
4(7,0)\end{array}$ & $0,016^{*}$ \\
\hline $\begin{array}{l}\text { Faktor resiko: } \\
\text { CHF } \\
\text { Sepsis } \\
\text { CKD } \\
\text { Kortikosteroid } \\
\text { Trauma } \\
\text { Koagulopati } \\
\text { Ventilator mekanik } \\
\text { HF } \\
\text { Hipotensi } \\
\text { Riwayat bleeding } \\
\end{array}$ & $\begin{array}{l}41(66,1) \\
20(32,3) \\
22(35,5) \\
18(29) \\
4(6,5) \\
4(6,5) \\
3(4,8) \\
6(9,7) \\
8(12,9) \\
0(0) \\
\end{array}$ & $\begin{array}{l}35(61,4) \\
31(54,4) \\
21(36,8) \\
15(26,3) \\
7(12,3) \\
6(10,5) \\
4(7,0) \\
3(5,3) \\
2(3,5) \\
1(1,8) \\
\end{array}$ & $\begin{array}{l}0,592 \\
0,015^{*} \\
0,878 \\
0,741 \\
0,273 \\
0,423 \\
0,615 \\
0,363 \\
0,065 \\
0,297 \\
\end{array}$ \\
\hline
\end{tabular}

*berbeda signifikan

Tabel 2. Gambaran jumlah penggunaan obat-obat ulserogenik pada kelompok lansoprazol dan pantoprazol selama perawatan di ICU

\begin{tabular}{llll}
\hline Jumlah obat ulserogenik & Lansoprazol & Pantoprazol & Nilai P \\
\hline $0-1$ & 33 & 25 & 0,587 \\
$2-3$ & 24 & 26 & \\
4 & 5 & 6 & \\
\hline
\end{tabular}

Tabel 3. Perbandingan kejadian perdarahan minor dan mayor antara kelompok lansoprazol dengan kelompok pantoprazol selama perawatan di ICU

\begin{tabular}{lllll}
\hline Kelompok terapi & Tidak perdarahan & \multicolumn{2}{l}{ Perdarahan (n,\%) } & Nilai P \\
\cline { 3 - 4 } & $\mathbf{( n , \% )}$ & $\begin{array}{l}\text { Perdarahan } \\
\text { minor }\end{array}$ & $\begin{array}{l}\text { Perdarahan } \\
\text { mayor }\end{array}$ & \\
\hline Lansoprazol & $48(77,4)$ & $1(1,6)$ & $13(21)$ & 0,057 \\
Pantoprazol & $35(61,4)$ & $5(8,8)$ & $17(29,8)$ & \\
\hline
\end{tabular}


Pada kelompok terapi lansoprazol, obat lansoprazol yang digunakan di ICU merupakan obat paten dari lansoprazol, dosis yang diberikan $30 \mathrm{mg}$ secara intaravena dengan aturan pakai 1 $\mathrm{x}$ sehari untuk indikasi profilaksis stress ulcers. Sedangkan pada kelompok terapi pantoprazol, obat pantoprazol yang diberikan kepada 57 pasien merupakan obat generik pantoprazol dengan dosis yang diberikan $40 \mathrm{mg}$ secara intravena $1 \mathrm{x}$ sehari untuk indikasi profilaksis stress ulcers.

Dari obat-obatan yang diterima oleh pasien terdapat obat-obat yang bersifat ulserogenik. Telah diketahui bahwa obat-obat ulserogenik juga dapat mempengaruhi perdarahan saluran cerna [13]. Adapun proporsi distribusi penggunaan obat-obat ulserogenik seperti kortikosteroid, analgesik, antiplatelet, dan antikoagulan antara kedua kelompok terapi tidak berbeda signifikan dengan nilai $p>0,05$. Distribusi penggunaan obatobat ulserogenik pada 2 kelompok terapi dapat dilihat pada tabel 2. Penggunaan obat golongan kortikosteroid yang digunakan di ICU antara lain metil prednisolon dan deksametason. Untuk penggunaan obat analgesik NSAIDs selama perawatan di ICU yaitu parasetamol, antalgin injeksi, ketorolac, dan kalium diklofenak. Selanjutnya obat antiplatelet yang digunakan yaitu aspirin dan clopidogrel, sedangkan untuk obat antikoagulan yang digunakan yaitu fondaparinux sodium. Pasien-pasien di ICU tidak hanya mendapatkan 1 jenis obat ulserogenik tetapi pada praktek kliniknya 1 pasien bisa menggunakan 2-4 obat-obat ulserogenik. Pada tabel 2 dapat dilihat distribusi jumlah penggunaan obat ulserogenik pada kelompok lansoprazol dan pantoprazol memiliki proporsi yang sama dengan nilai $p>0,05$ yaitu 0,587.

\subsection{Efektivitas Iansoprazol dan pantoprazol}

Untuk mengetahui efektivitas terapi sebagai profilaksis stress ulcers dengan melihat jumlah kejadian perdarahan baik mayor maupun minor pada kedua kelompok terapi. Adapun pada kelompok terapi lansoprazol, baik kejadian perdarahan mayor maupun minor lebih kecil dibandingkan dengan kelompok pantoprazol. Hasil perbandingan efektivitas penggunaan lansoprazol dan pantoprazol injeksi sebagai profilaksis stress ulcers pada pasien dengan resiko tinggi perdarahan dapat dilihat pada tabel 3 . Berdasarkan hasil analisis statistik diperoleh nilai $\mathrm{p}>0,05(\mathrm{p}=0,057)$ yang dapat diartikan bahwa tidak terdapat perbedaan efektivitas terapi antara kelompok lansoprazol dan kelompok pantoprazol meskipun dari jumlah kejadian perdarahan lebih banyak pada kelompok pantoprazol.

Ada beberapa faktor yang dapat mempengaruhi perbedaan efektivitas antara kelompok lansoprazol dan pantoprazol dalam mencegah kejadian perdarahan. Jika dilihat pada tabel 1, terdapat perbedaan proporsi resiko lama rawat di ICU antara kedua kelompok, dimana jumlah pasien dengan ICU stay $>7$ hari lebih banyak pada kelompok pantoprazol dibandingkan dengan kelompok lansoprazol. Begitu juga dengan proporsi distribusi pasien yang mengalami sepsis yang merupakan salah satu resiko terjadinya perdarahan tidak sama antara dua kelompok dimana jumlah pasien yang mengalami sepsis lebih banyak pada kelompok pantoprazol.

Pada penelitian yang dilakukan oleh Khoshbaten dkk. [14], sebesar 26,7\% pasien dari total pasien yang diteliti mengalami perdarahan mayor, hal ini berhubungan dengan lama rawat pasien. Oleh karena itu, tingginya jumlah pasien dengan lama rawat $>7$ hari pada kelompok pantoprazol bisa mempengaruhi besarnya jumlah kejadian perdarahan dan mempengaruhi ketercapaian klinik pada penggunaan pantoprazol. Adapun pada penelitian ini, kelompok karakteristik pasien berdasarkan jumlah resiko pasien selama di ICU disesuaikan dengan kondisi pasien. Selama penelitian, subjek pasien yang berhasil diinklusi rata-rata memiliki faktor resiko 2-4 resiko per pasien dimana resiko mayor dan resiko minor tidak pernah 
ditemukan terpisah pada kondisi pasien di ICU. Oleh karena itu, peneliti membagi karakteristik pasien berdasarkan jumlah faktor resiko menjadi 3 kategori. Untuk jumlah faktor resiko > 2 lebih banyak pada kelompok pantoprazol. Berdasarkan analisis statistik, karakteristikpasien berdasarkan jumlah faktor resiko ini diperoleh nilai $\mathrm{p}<0,05$ yaitu 0,016 yang berarti bahwa proporsi jumlah faktor resiko antara kelompok lansoprazol dan kelompok pantoprazol tidak sama. Pada tabel 4 dapat dilihat apakah perbedaan lama rawat, sepsis, dan jumlah faktor resiko mempengaruhi kejadian perdarahan pada penelitian ini. Pada tabel 4 dapat dilihat bahwa lama rawat $>7$ hari dan jumlah faktor resiko memiliki nilai $\mathrm{P}<0,05$, masing-masing dengan nilai $\mathrm{P}=0,001$ dan 0,03 .

Pada sebagian pasien baik pada kelompok lansoprazol maupun pantoprazol menggunakan obat-obat yang dapat beresiko mempengaruhi kejadian perdarahan lambung dimana penggunaan obat-obat yang bisa memicu ulserasi tersebar dalam 2 kelompok terapi. Pada tabel 5 dapat dilihat pengaruh penggunaan obat-obatan ulserogenik terhadap kejadian perdarahan pada pasien. Hasil dari analisis statistik diketahui bahwa penggunaan antiplatelet memiliki pengaruh yang signifikan terhadap kejadian perdarahan dengan nilai $\mathrm{P}<0,05$ yakni 0,007.

Pasien-pasien di ICU tidak hanya mendapatkan 1 jenis obat ulserogenik tetapi pada praktek kliniknya 1 pasien bisa menggunakan 2-4 obat-obat ulserogenik. Pada tabel 6 dapat dilihat distribusi jumlah penggunaan ulserogenik pada kelompok lansoprazol dan pantoprazol.

Penggunaan aspirin sebagai antiplatelet dapat mempengaruhi perdarahan tergantung dosis yang digunakan, dimana dosis 300 mg memiliki resiko $2 \mathrm{x}$ terhadap kejadian perdarahan [15]. Resiko kejadian perdarahan saluran cerna akibat penggunaan antiplatelet pada kelompok

Tabel 4. Hubungan faktor resiko yang memiliki perbedaan proporsi terhadap kejadian perdarahan

\begin{tabular}{|c|c|c|c|}
\hline Parameter & Tidak perdarahan (n, \%) & Stage $(n, \%)$ & Nilai $\mathbf{P}$ \\
\hline $\begin{array}{l}\text { Lama rawat: } \\
>7 \text { hari } \\
<7 \text { hari }\end{array}$ & $\begin{array}{l}19(50) \\
64(79)\end{array}$ & $\begin{array}{l}19(50) \\
17(21)\end{array}$ & $0,001^{*}$ \\
\hline $\begin{array}{l}\text { Sepsis } \\
\text { Tidak sepsis }\end{array}$ & $\begin{array}{l}31(37,3) \\
52(62,7)\end{array}$ & $\begin{array}{l}20(55,6) \\
16(44,4)\end{array}$ & 0,065 \\
\hline $\begin{array}{l}\text { Jumlah faktor resiko: } \\
1-2 \\
3-4 \\
>4\end{array}$ & $\begin{array}{l}49(77,8) \\
32(62,7) \\
2(40)\end{array}$ & $\begin{array}{l}14(22,2) \\
19(37,3) \\
3(60)\end{array}$ & $0,03^{*}$ \\
\hline
\end{tabular}

*berbeda signifikan

Tabel 5. Perbandingan kejadian perdarahan pada pasien yang menggunakan obat ulserogenik selama perawatan di ICU

\begin{tabular}{llll}
\hline Parameter & Tidak perdarahan (n, \%) & Stage (n, \%) & Nilai P \\
\hline Kortikosteroid & 11 & 30 & 0,556 \\
Analgesik NSAIDs & 16 & 29 & 0,326 \\
Antiplatelet & 9 & 43 & $0,007^{*}$ \\
Antikoagulan & 2 & 16 & 0,055 \\
\hline
\end{tabular}

*berbeda signifikan

lansoprazol dan pantoprazol sama karena proporsi penggunaan obat antiplatelet antara dua kelompok tidak berbeda yang dapat dilihat pada tabel 6 dengan nilai $p>0,05$. Pada penelitian ini, penggunaan aspirin dengan dosis $160 \mathrm{mg}$ dan 320 mg tidak mempengaruhi terjadinya perdarahan 
Tabel 6. Gambaran jumlah penggunaan obat-obat ulserogenik pada kelompok lansoprazol dan kelompok pantoprazol selama perawatan di ICU

\begin{tabular}{llll}
\hline Jumlah obat ulserogenik & Lansoprazol & Pantoprazol & Nilai P \\
\hline $0-1$ & 33 & 25 & 0,587 \\
$2-3$ & 24 & 26 & \\
4 & 5 & 6 & \\
\hline
\end{tabular}

*berbeda signifikan

pada pasien. Jumlah penggunaan obat-obat ulserogenik pada kelompok lansoprazol dan pantoprazol yang dapat dilihat pada tabel 6 memiliki proporsi yang sama. Oleh karena itu, pada penelitian ini efektivitas terapi lansoprazol dan pantoprazol tidak dipengaruhi oleh jumlah penggunaan obat ulserogenik.

\section{Keterbatasan Penelitian}

Peneliti tidak dapat mengontrol faktor-faktor yang dapat mempengaruhi efektivitas terapi seperti jumlah komorbid dan penggunaan obat-obatan khususnya obat ulserogenik.

\section{Kesimpulan}

Pada kelompok lansoprazol dan pantoprazol, pasien yang tidak mengalami kejadian perdarahan masing-masing sebesar 77,4\% dan 61,4\%. Penggunaan lansoprazol dan pantoprazol sebagai profilaksis stress ulcers di ICU secara statistik tidak berbeda signifikan dengan nilai $p>0,05$. Hasil efektivitas ini juga dipengaruhi oleh lama rawat dan jumlah komorbid dengan proporsi lebih banyak pada kelompok pantoprazol.

\section{Ucapan Terima Kasih}

Ucapan terimakasih disampaikan kepada Lembaga Pengelolaan Dana Pendidikan (LPDP) Kementrian Keuangan Negara yang telah memberikan bantuan dalam penyelesaian penelitian ini dan RSUD Sleman yang telah memberikan izin dalam pengambilan data penelitian.

\section{Daftar Pustaka}

1. Mutlu GM, Mutlu EA, Factor P. GI Complications in patients receiving mechanical ventilation. Chest. 2001;119(4):1222-41.

2. Barkun AN, Bardou M, Pham CQ Martel M. Proton pump inhibitors vs. histamine 2 reseptor antagonists for stress-related mucosal bleending prophylaxis in critically ill patients: a meta-analysis. The American journal of gastroenterology. 2012:107(4):507.

3. Spirt MJ, Stanley S. Update on stress ulcer prophylaxis in critically ill patients. Critical care nurse. 2006;26(1):18-28.

4. Mohamad MS, Shamsuddin N, Tan KM. Appropriateness of stress ulcer prophylaxis among older adults admitted to general medical wards in a university hospital. European Geriatric Medicine. 2015;6(2):119-23.

5. Barkun AN, Adam V, Martel M, dan Marc B. Cost-Effectiveness Analysis: Stress Ulcer Bleeding Prophylaxis with Proton Pump Inhibitors, H2 Receptor Antagonists. Value in Health. 2013;16: 14-22.

6. Udeh BL, Udeh C, Hata JS. Cost-effectiveness of stress ulcer propalaxis: role of proton pump inhibitors. Am J Pharm Benefit. 2010;2(5):30412.

7. Shin JM, Kim N. Pharmacokinetics and Pharmacodynamics of the Proton Pump Inhibitors. Journal of Neurogastroenterology and Motility. 2013;19(1): 25-35.

8. Chubineh S, Birk J. Proton Pump Inhibitors: The Good, the Bad, and the Unwanted. Southern Medical Journal. 2012;105(11):613-8.

9. Heidelbaugh JJ, Inadomi JM. Magnitude and 
economic impact of inappropriate use of stress ulcer prophylaxis in non-ICU hospitalized patients. Am J Gastroenterol. 2006;101(10):22005.

10. Alhazzani W, Alshahrani M, Moayyedi P, Jaeschke R. Stress ulcer prophylaxis in critically ill patients: Review of the evidence. Pol Arch Med Wewn. 2012;122(3):107-14.

11. Zeitoun A, Zeineddine M, Dimmasi H. Stress Ulcer Prophylaxis Guideline: Are They Being Implemented in Labanese Health Care Centers ? World Journal of Gastrointestinal Pharmacology and Therapeutics. 2011;2(4): 27-33.

12. Krag M, Perner A, Wetterslev J, et all. Stress ulcer prophylaxis with a proton pump inhibitor versus placebo in critically ill patients (SUPICU trial): study protocol for a randomised controlled trial. Trials. 2016;17(1):205.

13. Yasuda H, Matsuo Y, Sato Y, Ozawa S, Ishigooka S, Yamashita M, Yamamoto H, Itoh F. Treatment and prevention of gastrointestinal bleeding in patients receiving antiplatelet therapy. World Journal of Critical Care Medicine. 2015;4(1):406.

14. Khoshbaten M, Farzin H, Fattahi E, Entezarie AM. Significant Upper GI - Bleeding In Critically Ill Patients. The Internet Journal of Gastroenterology. 2006;5:2.

15. Lanas A, García-Rodríguez LA, Arroyo MT. Risk of upper gastrointestinal ulcer bleeding associated with selective cyclo-oxygenase-2 inhibitors, traditional non-aspirin nonsteroidal antiinflammatory drugs, aspirin and combinations. Gut. 2006;55(12): 1731-8. 